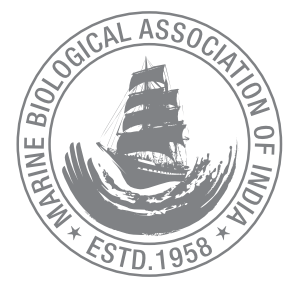

\title{
New record of Abralia (Heterabralia) siedleckyi Lipinski, 1983 (Cephalopoda: Enoploteuthidae) from south-eastern Arabian Sea with some remarks about its biology
}

\author{
K. K. Sajikumar*, Marek R. Lipinski', V. Venkatesan, G. Sasikumar and K. S. Mohamed \\ ICAR-Central Marine Fisheries Research Institute, Kochi-682 018, Kerala, India. \\ 'Department of Ichthyology and Fisheries Science, Rhodes University, P.O. Box 94 Grahamstown 6140, South Africa. \\ *Correspondence e-mail: kksajikumar@yahoo.co.in
}

Received: 15 Oct 2018 Accepted: 30 Dec 2018 Published: 15 Jan 2019

Original Article

\begin{abstract}
Specimens of oceanic squid, Abralia (Heterabralia) siedleckyi Lipinski, 1983 were collected from the south-eastern Arabian Sea using midwater trawl (horizontally at $200 \mathrm{~m}$ depth) during night operations in two cruises on 18 April 2015 and 26 February 2017. Description and morphological measurements of the specimens are provided. The record of this mesopelagic squid from the Arabian Sea is an addition to the cephalopod fauna of the Indian Ocean and India. The statolith based age analysis indicates that a $29.1 \mathrm{~mm}$ dorsal mantle length specimen had 93 day's age with a growth rate of $0.31 \mathrm{~mm}$ DML/day.
\end{abstract}

Keywords: Arabian Sea, Enoploteuthidae, statolith, mesopelagic, India, photophore

\section{Introduction}

Squids of the family Enoploteuthidae are recognised as "myctophid fishes" of the squid world (Young and Harman, 1985 ) and they play significant role in the trophic web of the epipelagic and mesopelagic zones of the open ocean (Santo et al., 2001; Guerra et al., 2010). Squids of the genus Abralia Gray 1849, family Enoploteuthidae, are key members in the micronektonic groups in the tropical and subtropical world oceans (Reid et al., 1991).

Twenty nominal species of Abralia are known worldwide (Young and Tsuchiya, 2018). Eight enoploteuthid squids of the genus Abralia Gray, 1846 have been recorded from the Indian Ocean. They are, Abralia armata (Quoy and Gaimard, 1932), A. and amanica Goodrich, 1896, A. steindachneri Weindl, 1912, A. renschi Grimpe, 1931, A. spaercki Grimpe, 1931, A. lucens Voss, 1963, A. marisarabica Okutani, 1983, A. trigonura Berry, 1913 and A. fasciolata Tsuchiya, 1991 (Silas, 1968; Okutani, 1983; Silas et al., 1985; Nesis, 1986; Okutani and Tsukada, 1988; Tsuchiya, 1991). Tsuchiya and Okutani, (1988) suggested that $A$. lucens is a junior synonym of $A$. multihamata.

Abralia siedleckyi is assessed as "Data deficient", in the IUCN Red List of threatened species, therefore further research is 
recommended in order to determine the precise distribution, population dynamics, life history and ecology, and potential threats, if any, affecting this species (Barratt and Allcock, 2014).

Recent studies highlight the need of dedicated research to improve knowledge of oceanic cephalopods of Arabian Sea and Indian EEZ (Sajikumar et al., 2018). Abralia siedleckyi is a poorly known species and Hidaka and Kubodera (2000) recommend further investigation to understand the range and distribution for the species. Herein, we report the first record of small enoploteuthid squid $A$. siedleckyi from south-eastern Arabian Sea.

\section{Material and methods}

Three individuals of $A$. siedleckyi Lipinski, 1983 were collected from the south-eastern Arabian Sea by "FRV Silver Pompano" on 18 April 2015 and 26 February 2017. During the four cruises a total of sixteen stations were covered. Specimens were collected using a mid-water trawl with a $10 \mathrm{~m}^{2}$ mouth opening and an $18 \mathrm{~mm}$ mesh codend towed horizontally for $1 \mathrm{~h}$ at a depth of $200 \mathrm{~m}$ at night ( 23.00 to $24.00 \mathrm{~h}$ ).

The animals were stored initially in $90 \%$ ethanol, after one month transferred to $5 \%$ formalin. Morphometric measurements such as dorsal mantle length (DML), mantle width (MW), arm length (AL1, AL2, AL3, and AL4), fin length (FL), fin width (FW), tentacle length $(\mathrm{TL})$ and club length $(\mathrm{CL})$ of specimens were measured to the nearest $\mathrm{mm}$ as recommended by Roper and Voss (1983). Indices of length were expressed as percentage of dorsal mantle length. One individual was damaged so it could not be measured. Photographic images were taken with a Nikon stereozoom microscope (SMZ-25). Vertical water column profiles were determined at stations by using an underway CTD system (Ocean Science, USA) with sensors for pressure, temperature and conductivity. Data were converted to Pressure $=$ depth and conductivity $=$ salinity by using Sea-Bird software.

Single mature female preserved in ethanol was aged using statolith microstructure according to Arkhipkin and Shcherbich (2012).

Oviducal egg counts were made on preserved specimens. The oviducts were removed from the squid and then eggs were counted. Oocyte diameters $(n=30)$ were measured using a microscope. The gonadosomatic index (GSI) was calculated as

$\mathrm{GSI}=(G W / B W) \times 100$

Where $G W$ is gonad weight and $B W$ is body weight.

\section{Results}

Three individuals (one mature female and two mature male) of $A$. siedleckyi were collected from $200 \mathrm{~m}$ depth during night by using mid water trawl net in the south-eastern

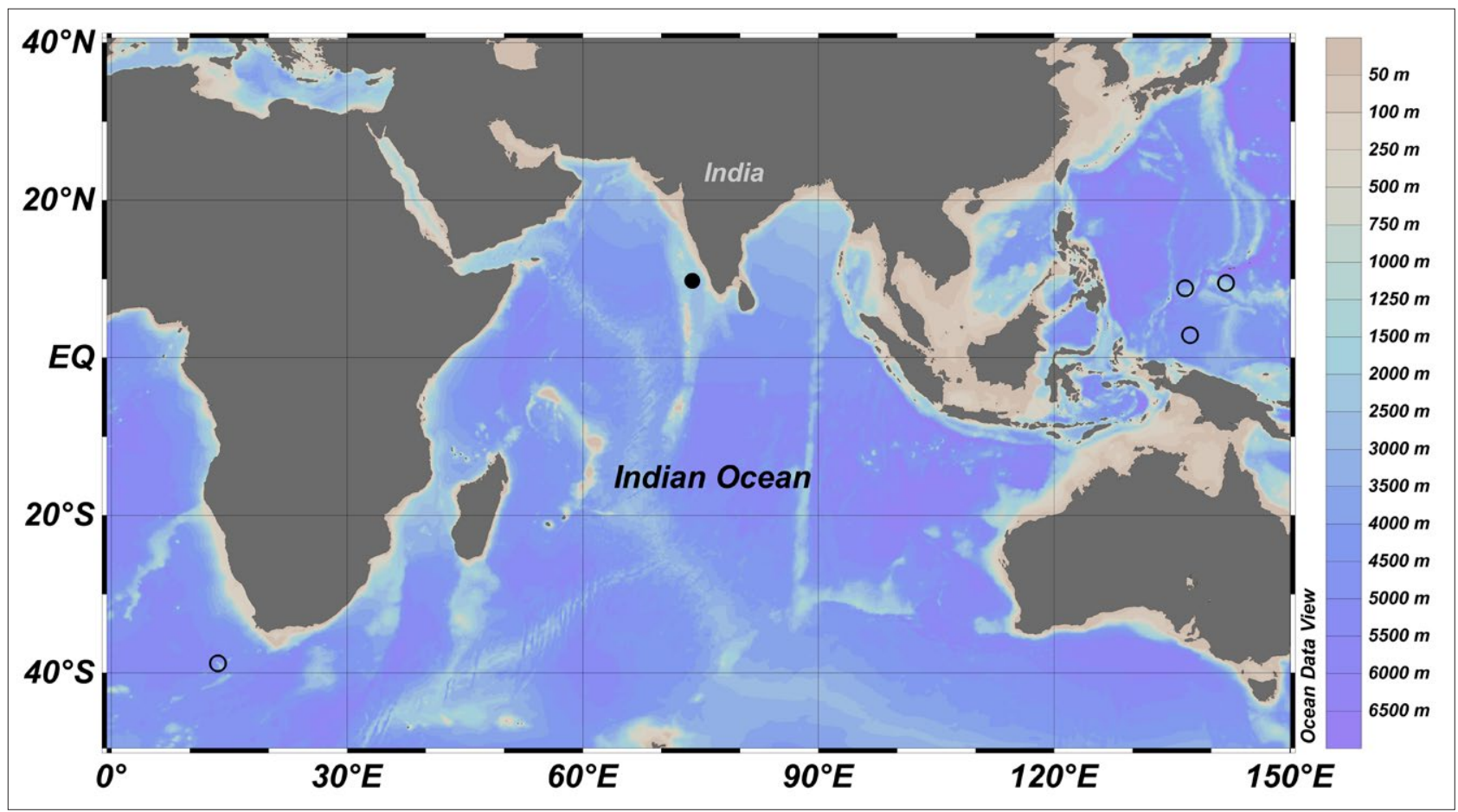

Fig. 1. Map showing the location of earlier distribution records of $A$. siedleckyi (open circle) and the new distribution records (closed circle). 


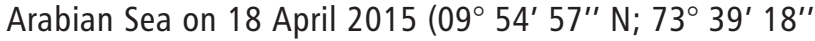

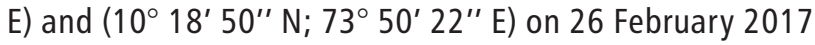
(Fig. 1). Bottam depths at these stations were 2229 and $1870 \mathrm{~m}$ respectively. The surface water temperature was 30.4 and $30.8^{\circ} \mathrm{C}$ and salinity were 34.06 and $34.2 \mathrm{psu}$ respectively. Temperature and salinity at $200 \mathrm{~m}$ depth in both stations were 15.2 and $14.8^{\circ} \mathrm{C}$ and 35.2 and 34.9 psu respectively. Single mature female individual was deposited in the Designated National Repository (DNR), CMFRI, India with accession number (DH. 1.1.1.1).

\section{Description}

The present specimens agree with the description of Lipinski (1983). The animal had DML 18.3, 20.5 and $29.1 \mathrm{~mm}$ and weighed $1.6,1.8$ and $2.1 \mathrm{~g}$ respectively. The mantle is conical and wide at the anterior margin. Ventral mantle is covered with small photophores arranged longitudinally (Fig. 2). Fins are large and extending to posterior tip of tail ( $\mathrm{FLI}=47$ to $59 ; \mathrm{FWI}=90$ to 92). The distal tip of ventral mantle is semigelatinous, lacking chromatophores. The funnel is large. The mantle funnel locking apparatus consists of a straight groove on the mantle. The arm formula was $4>2>3>1$ and arm 1 to 3 are keeled. Arms bear two rows of hooks with bi-serial rows of suckers on distal portion. The detailed morphometric measurements and indices are provided in Table 1.

Photophore pattern of the ventral region of the eyeball is the most distinct character. There are five photophores; posterior extra-large, oval, creamy white; small round orange; smallmedium round orange; small round orange; anterior larger

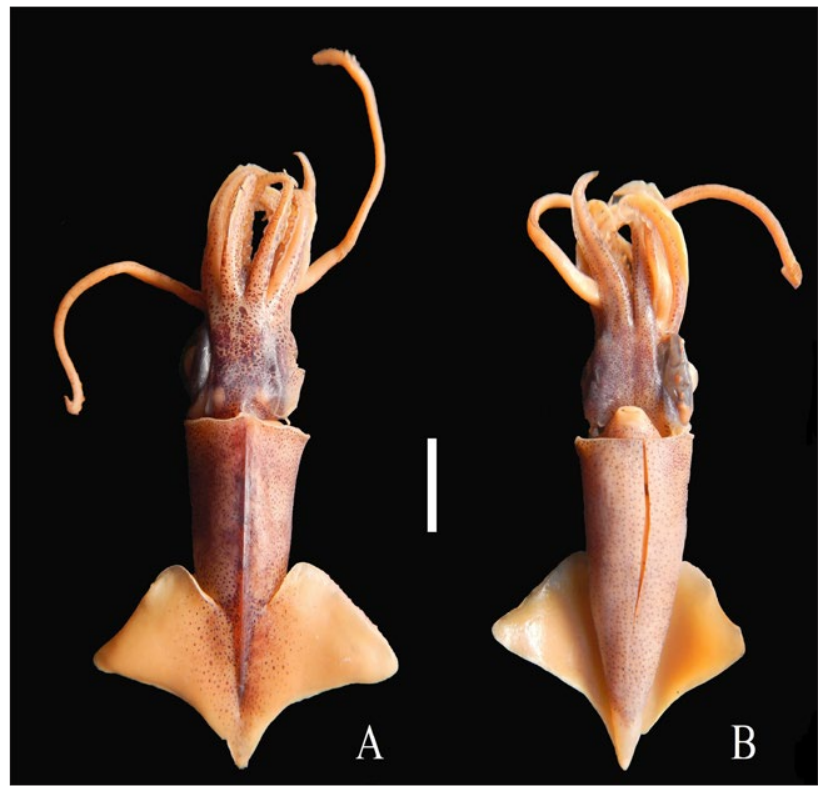

Fig. 2. A. siedleckyi: A) Dorsal view; B) Ventral view of $29 \mathrm{~mm} \mathrm{DML}$ specimen $($ Scale bar $=1 \mathrm{~cm})$
Table 1. Morphometric measurements and indices in relation to mantle length of A. siedleckyi from southeastern Arabian Sea

\begin{tabular}{lllll}
\hline & \multicolumn{2}{c}{ Female } & Male \\
\hline Measurements & $(\mathrm{mm})$ & Indices & $(\mathrm{mm})$ & Indices \\
\hline Dorsal mantle length & 29.1 & & 18.3 & \\
\hline Ventral mantle length & 27.4 & 94.1 & 16.2 & 88.5 \\
\hline Head length & 10.1 & 36.8 & 8.3 & 45.3 \\
\hline Head width & 10.3 & 35.4 & 7.25 & 39.6 \\
\hline Fin length & 17.4 & 59.7 & 8.7 & 47.5 \\
\hline Fin width & 26.4 & 90.7 & 17 & 92.9 \\
\hline Mantle width & 10.6 & 36.4 & 7.2 & 39.3 \\
\hline First arm length & 10.3 & 35.4 & 5.8 & 31.6 \\
\hline Second arm length & 13 & 44.6 & 6.8 & 37.1 \\
\hline Third arm length & 12.8 & 43.9 & 6.6 & 36.1 \\
\hline Fourth arm length & 13.1 & 45.1 & 7.5 & 40.9 \\
\hline Tentacle length & 30.3 & 104.1 & 20.2 & 110.4 \\
\hline Tentacular club length & 4.8 & 16.5 & 3.5 & 19.1 \\
\hline
\end{tabular}

than medial, slightly oval, creamy white (Fig. 3 (A)). The dorsal part of eyelid bears 16 black photophores.

The tentacle is long, slender, length greater than mantle length ( $\mathrm{TLI}=104$ to 110$)$. Tentacular clubs small with two to three hooks ( $\mathrm{TCl}=16$ to 19) (Fig. 3 (B)). The photophores were present on the ventral part of the arms IV, head, eyeballs, funnel and mantle.

The highest morphometric index was found for tentacle length $(T L I=104.12)$, while the lowest was observed for the tentacular club $(T L I=4.8)$. The fin width index was 90.72 and lengths were 50.79. Males had left arm hectacotylised, there were 10 normal hooks proximally. After hooks,

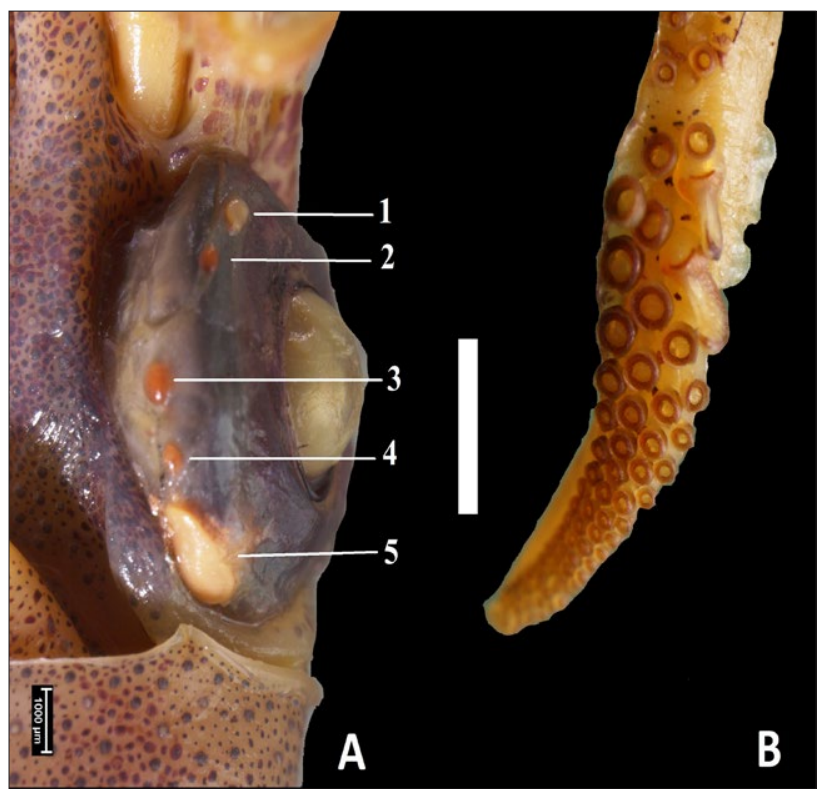

Fig. 3. A. siedleckyi $\mathrm{A}=$ left eye ball with five ocular photophores, $B=$ oral view tentacular club (scale bar $=1 \mathrm{~mm}$ ) 
a semicircular ventral flap lies in distal half of the arm. The dorsal flap lies distally to the ventral one. The mature male squid with $18.3 \mathrm{~mm}$ DML have 46 spermatophores (2.97 $\mathrm{mm}$ to $3.17 \mathrm{~mm}$ length).

\section{Statolith microstructure}

The statolith of $A$. siedleckyi has a broadly rounded lateral dome, a fairly straight rostrum and a distinct dorsal dome and large wing. The statolith had a total length of $790 \mu \mathrm{m}$. The statolith index was $2.71 \%$ in relation to DML. The mature female had 93 increments and the daily growth rate was estimated as 0.31 $\mathrm{mm} \mathrm{DML/day} \mathrm{(Fig.} \mathrm{4).}$

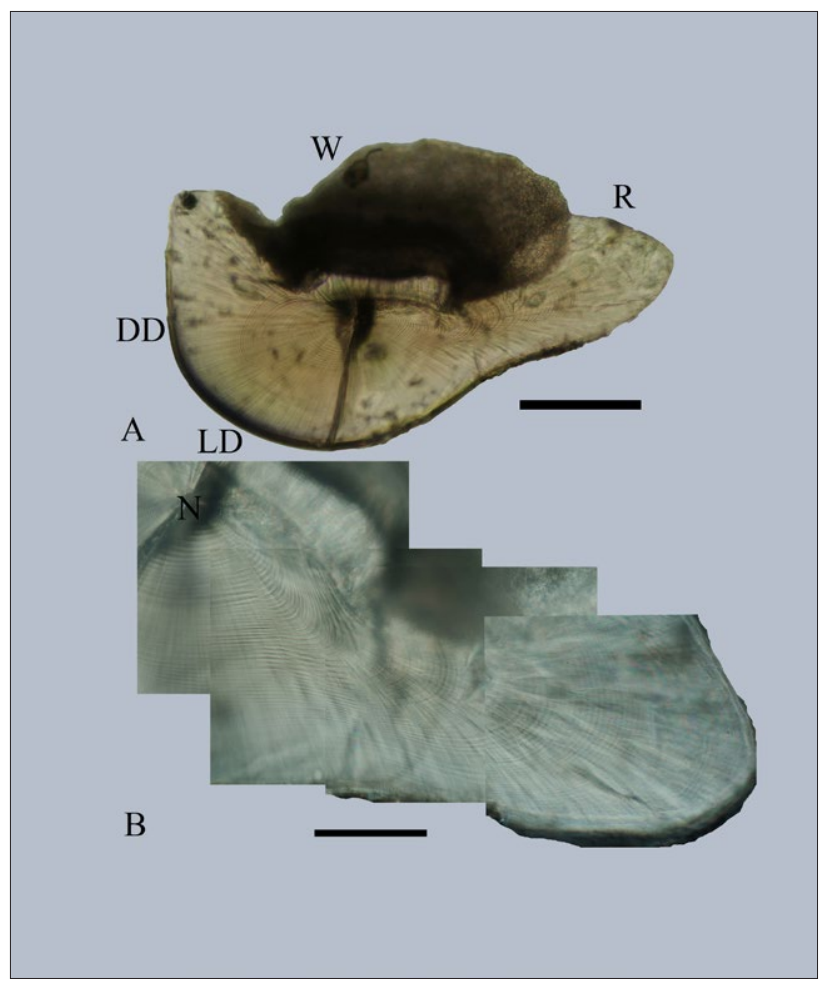

Fig. 4. Statolith microstructure of $A$. siedleckyi female $(A=$ general view of statolith) $(D M L=29.1 \mathrm{~mm}): W=$ wing, $R=$ rostrum, $D D=$ dorsal dome, $L D=$ lateral dome; $A=; B=$ details of periphery of statolith with increments: $N=$ nucleus (scale bar $=100 \mu \mathrm{m}$ )

\section{GSI and number of eggs}

The weight of the gonad was $0.49 \mathrm{~g}$ and gonadosomatic index was $23.3 \%$. Number of oviducal eggs was 284 with the diameter range from 590 to $712 \mu \mathrm{m}$ (mean: $640 \mu \mathrm{m}$ ).

\section{Discussion}

The Indian Ocean cephalopod fauna is still poorly described and nothing is known about the biology of several species (Piatkowski and Welsch, 1991). Earlier zoogeography of pelagic cephalopods of Arabian Sea was investigated in eastern Arabian Sea (Silas, 1968) and northern Arabian Sea (Piatkowski and Welsch, 1991). Silas (1968) reported occurrence of $A$. andamanica from Arabian Sea throughout the year except January, September and October. Recently some new sighting records of deep-sea cephalopods have been reported from the south-eastern Arabian Sea (Rithin et al., 2015, Sajikumar et al., 2016, 2017, 2018).

Previously A. siedleckyi has been recorded from the southern temperate waters of South Atlantic off Cape Town (original description) (Lipinski, 1983) and western tropical Pacific (Hidaka and Kubodera, 2000).

The present record of $A$. siedleckyi is first from Arabian Sea as well as Indian Ocean and the study area shares the occurrence of $A$. andamanica, and $A$. marisarabica. The first two species are reported from south-eastern Arabian Sea and A. marisarabica reported from northern Arabian Sea (Silas, 1968; Piatkowski and Welsch, 1991). A. siedleckyi is very similar to $A$. heminuchalis which is known from tropical waters of the Pacific Ocean and the two species may be synonymous (Tsuchiya and Young, 2014) (Table 2).

According to Lipinski (1983) A. siedleckyi and A. andamanica (which is widely distributed) are closely related but differ in characteristics such as size and shape of the photophores on the eyeballs, shape of hectocotylus and proportion of manus/dactylus.

Table 2.Key morphological characters of Abralia squids recorded from Arabian Sea

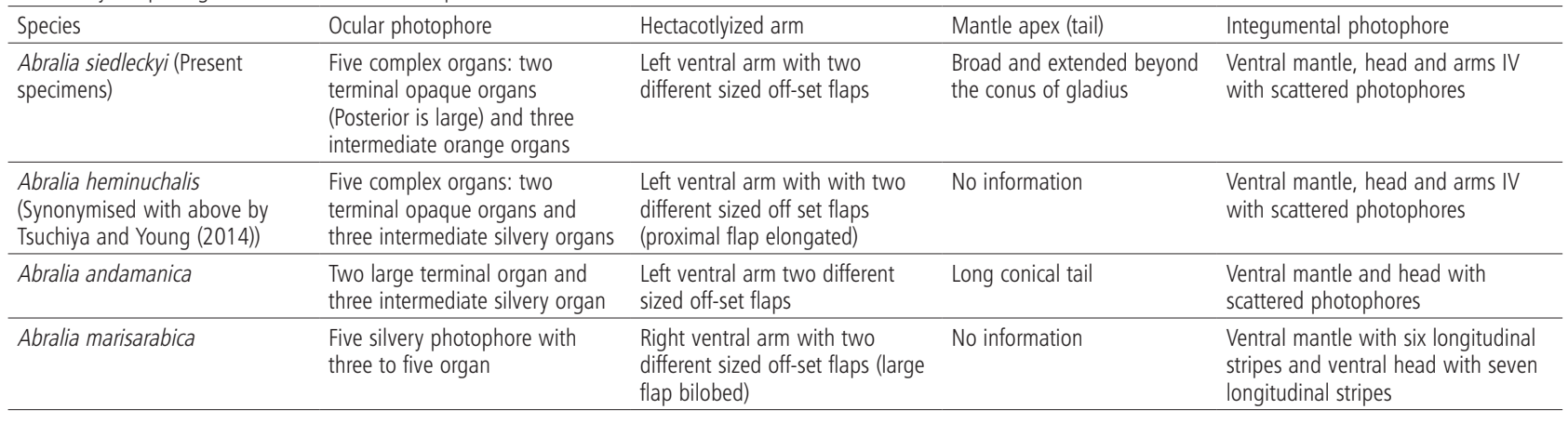


Daily increments for Abralia trigonura have been validated (Bigelow, 1992) and we assume that increments are formed daily for $A$. siedleckyialso. The age estimated based on statolith increment analysis agree with earlier studies on Abralia trigonura having a maximum life span of $\sim 6$ months from Pacific Ocean (Young and Mangold, 1994). The mean egg number determined in the oviduct of Abralia verany from eastern Mediterranean Sea was 251 (Salman and Laptikhovsky, 2005), which is comparable to our estimate of 284 eggs.

The present report provides new addition to cephalopod fauna of Arabian Sea as well as Indian Ocean. Further detailed studies are required to understand distribution and biology of deep-sea cephalopods of Arabian Sea.

\section{Acknowledgements}

We are thankful to Dr. A. Gopalakrishnan, Director, ICAR - CMFRI for facilities. We are also grateful to the Captain and crew of "FRV Silver Pompano" for their help during the cruise.

\section{References}

Arkhipkin, A. I. and Z. N. Shcherbich. 2012. Thirty years' progress in age determination of squid using statoliths. J. Mar. Biol. Assoc. UK, 92: 1389 - 1398. https://doi.org/ 10.1017/S0025315411001585.

Barratt, I. and L. Allcock. 2014. Abralia siedleckyi. The IUCN Red List of Threatened Species 2014: e. T163157A978320. http://dx.doi.org/10.2305/IUCN.UK.2014-1. RLTS.T163157A978320.en/ (accessed 25 May 2017).

Bigelow, K. A. 1992. Age and growth in paralarvae of the mesopelagic squid Abralia trigonura based on daily growth increments in statoliths. Mar. Ecol. Prog. Ser., 82: 31 - 40. https://doi.org/10.3354/meps082031

Guerra, A., L. Allcock and J. Pereira. 2010. Cephalopod life history, ecology and fisheries: An introduction. Fish. Res., 106: 117 - 124.

Hidaka, K. and T. Kubodera. 2000. Squids of the genus Abralia (cephalopoda: Enoploteuthidae) from the western tropical pacific with a description of Abralia omiae, a new species. Bull. Mar. Sci., 66 (2): 417 - 443.

Lipinski, M. 1983. A description of a new species of enoploteuthid cephalopod, Abralia siedleckyi spec. nov., with some remarks on Abralia redfieldi Voss, 1955. Veliger, 25: $255-265$.

Nesis, K. N. 1986. Cephalopods of seamounts in the western Indian Ocean. Okeanotogia, 26: 123 - 130. (Russian with English abstract).

Okutani, T. 1983. Abralia marisarabica, a new enoploteuthid squid from the Arabian Sea (Cephalopoda: Oegopsida). Bull. Natl. Sci. Mus. Tokyo, 9: 161 - 168.

Okutani, T. and S. Tsukada. 1988. Squids eaten by lancet fish and tunas in the tropical Indo-Pacific Oceans. J. Tokyo. Fish, 75: 1 - 44.
Piatkowski, U. and W. Welsch. 1991. On the distribution of pelagic cephalopods in the Arabian Sea. Bull. Mar. Sci., 49: 186 - 198.

Reid, S. B., J. Hirota, R. E. Young and L. E. Hallacher. 1991. Mesopelagic boundary community in Hawaii: micronekton at the interface between neritic and oceanic ecosystems. Mar. Bio., 109: 427 - 440.

Rithin, J., R. Daniel., F. T. Jose, K. K. Sajikumar, R. Renju, K. K. Prajith and M. P. Ramesan. 2015. First record of Asperoteuthis acanthoderma (Lu, 1977) (Cephalopoda:Oegopsida: Chiroteuthidae), from the Arabian Sea. Int. J. Sci. Res., 5: 1 - 5.

Roper, C. F. E. and G. L. Voss. 1983. Guidelines for taxonomic descriptions of Cephalopod species. Mem. Natl. Mus. Victoria, 44: 49 - 63.

Sajikumar, K. K., V. Venkatesan, C. P. Binesh, Gishnu Mohan, N. K. Sanil, V. Kripa and K. S. Mohamed. 2018. Presence of the Wondrous jewel squid Histioteuthis miranda (Cephalopoda: Histioteuthidae) in the eastern Arabian Sea and determination of its age from statoliths. Thalassas. https://doi.org/10.1007/ s41208-018-0076-Z.

Sajikumar, K. K., A. I. Arkhipkin, V. Venkatesan, Jestin Joy, C. P. Bineesh, G. Sasikumar and K. S. Mohamed. 2017. Range extension of a bathypelagic squid, Bathyteuthis bacidifera (Cephalopoda: Bathyteuthidae) to the south Arabian Sea with special reference to its age and growth pattern. Mar. Biodiver., 48:1511 - 1518. https:// doi.org/10.1007/s12526-017-0655-x.

Sajikumar, K. K., V. Venkatesan, R. Jeyabaskaran, Abbas Muhammed and K. S. Mohamed. 2016. First record of the glass octopus Vitreledonella richardi (Cephalopoda: Vitreledonellidae) from the Arabian Sea. Mar. Biodivers. Rec., 9: 53. https://doi: 10.1186/s41200-016-0041-6.

Salman, A. and V. Laptikhovsky. 2005. Fecundity and spawning of Abralia verany (Rüppell, 1844) (Cephalopoda: Enoploteuthidae) in the Aegean Sea. Sci. Mar., 69: $211-214$.

Santo, M. B., M. R. Clarke and G. J. Pierce. 2001. Assessing the importance of cephalopods in the diets of marine mammals and other top predators: problems and solutions. Fish. Res., 52:121 - 139.

Silas, E. G. 1968. Cephalopoda of the west coast of India collected during the cruises of the research vessel Varuna, with a catalogue of the species known from the Indian Ocean in: Proceedings of the Symposium on Mollusca. Marine Biological Association of India, Bangalore, pp. 277 - 359.

Silas, E. G., P. Nair, M. Meiyappan and R. Sarvesan. 1985. Resume of the work on cephalopods of the Indian Ocean in: Silas E.G (Eds), Cephalopod bionomics, fisheries and resources of the exclusive economic zone of India, CMFRI bulletin 37, pp. $5-12$

Tsuchiya, K. and R. E. Young. 2014. Abralia siedleckyi Lipinski 1983. Version 21 January 2014 (under construction). http://to/web.org/Abralia siedleckyi/19656/2014.21 in The Tree of Life Web Project, http://tolweb.org.(accessed 25 May 2017).

Tsuchiya, K. 1991. Abralia fasciolata, a new species of enoploteuthid squid from the western Indian Ocean (Cephalopoda: Oegopsida). Bull. Natl. Sci. Mus., 17: 69 - 79.

Tsuchiya, K. and T. Okutani. 1988. Subgenera of Enoploteuthis, Abralia and Abraliopsis of the squid family Enoploteuthidae (Cephalopoda, Oegopsida). Bull. Natl. Sci. Mus., 14: $119-136$.

Young, R. E. and K. Tsuchiya. 2018. Abralia Gray 1849. Version 29 March 2018 (under construction). http://to/web.org/Abralia/19642/2018.03.29 in The Tree of Life Web Project, http://tolweb.org/(accessed 15 April 2018)

Young, R. E. and R. F. Harman. 1985. Early life history stages of Enoploteuthid Squid (Cephalopoda: Teuthoidea) from Hawaiian waters. Vie. Milieu, 35: 181 - 201.

Young, R. E. and K. M. Mangold. 1994. Growth and reproduction in the mesopelagic boundary squid Abralia trigonura. Mar. Biol., 119: 413 - 421. https://doi.org/ 10.1007/BF00347538. 